\title{
Absence from work due to occupational and non-occupational accidents
}

\author{
Jørgensen, Kirsten; Laursen, Bjarne
}

Published in:

Scandinavian Journal of Public Health

Link to article, DOI:

$10.1177 / 1403494812468518$

Publication date:

2013

Document Version

Early version, also known as pre-print

Link back to DTU Orbit

Citation (APA):

Jørgensen, K., \& Laursen, B. (2013). Absence from work due to occupational and non-occupational accidents. Scandinavian Journal of Public Health, 41(1), 18-24. https://doi.org/10.1177/1403494812468518

\section{General rights}

Copyright and moral rights for the publications made accessible in the public portal are retained by the authors and/or other copyright owners and it is a condition of accessing publications that users recognise and abide by the legal requirements associated with these rights.

- Users may download and print one copy of any publication from the public portal for the purpose of private study or research.

- You may not further distribute the material or use it for any profit-making activity or commercial gain

- You may freely distribute the URL identifying the publication in the public portal

If you believe that this document breaches copyright please contact us providing details, and we will remove access to the work immediately and investigate your claim. 
Absence from work due to occupational and non-occupational accidents, page 1

\title{
Absence from work due to occupational and non-occupational accidents
}

\author{
Authors: \\ Kirsten Jørgensen, Department of management Engineering \\ The Technical University of Denmark, Bygn. 424, 2800 Kgs. Lyngby, Denmark \\ Bjarne Laursen, National Institute of Public Health, University of Southern Denmark, $\varnothing$ ster \\ Farimagsgade 5A, DK-1353 Copenhagen, Denmark
}

\section{Author responsible for correspondence:}

Kirsten Jørgensen, Department of management Engineering

The Technical University of Denmark, Bygn. 424, 2800 Kgs. Lyngby, Denmark

Phone: 45452551 49, e-mail: kirj@man.dtu.dk 
Absence from work due to occupational and non-occupational accidents, page 2

\section{Abstract}

\section{Aims}

The aim of the present study is to investigate absence from work in Denmark due to occupational and non-occupational accidents.

\section{Background}

Since the beginning of the last decade, political focus has been placed on the population's working capacity and the scope of absence due to illness. Absence from work is estimated at between $3 \%-6 \%$ of working hours in the EU and costs are estimated at approximately $2.5 \%$ of GNP.

\section{Methods}

Victims of accidents treated at two emergency departments were interviewed regarding absence for the injured, the family, and others. All answers were linked to the hospital information on the injury, so that it was possible to examine the relation between absence and injury type, and cause of the accident.

\section{Results}

In total, 1,479 injured persons were interviewed. $36 \%$ of these reported absence from work by themselves or others. In mean, an injury caused 3.21 days of absence. Based on this the total absence due to injuries in Denmark was estimated to $1,822,000$ workdays, corresponding to approximately $6 \%$ of the total absence from work due to all types of illness. Non-occupational injuries resulted in more absence than did occupational injuries.

\section{Conclusions}

Absence due to accidents contributes to a considerable part of the total absence from work, and nonoccupational accidents cause more absence than did occupational accidents 
Absence from work due to occupational and non-occupational accidents, page 3

Keywords: Absence from work, Occupational and non-occupational accidents, Type of injury, Type of accidents. 
Absence from work due to occupational and non-occupational accidents, page 4

\section{Introduction}

The aim of the present study is to investigate absence from workplaces in Denmark due to both occupational and non-occupational accidents, including the absence of the victim as well as of those who has absence from their work because they help the victims in the situation e.g. relatives, colleagues, and other persons. Absence from work is estimated at between $3 \%-6 \%$ of working hours in the EU and costs roughly $2.5 \%$ of the GNP ${ }^{1}$. In Denmark it is estimated that absence from work due to illness costs around DKK 32 billion (4.3 billion Euro) each year. This has led to the Danish government creating an action plan in order to reduce absence due to illness ${ }^{2}$ just as there has been focus on absence due to illness on a European level ${ }^{3}$. In European studies, ${ }^{3}$, absence due to illness stems from health problems, where especially musculoskeletal problems and respiratory diseases are the two most important causes. ${ }^{1}$ While long-term absence due to serious illness increases the risk for expulsion from the job market, the short-term absence due to less serious illness is the most important cause of absence due to illness ${ }^{4}$. Chartered Institute of Personnel and Development (CIPD) 2003 found that $9 \%$ of the absence from work was due to occupational injuries and $7 \%$ due to other injuries.

For the non-manual workers the accidents represents $4 \%$ of the causes ${ }^{4}$. A study of causes for longterm absence due to illness in Denmark using a number of registers has not investigated the accidents' influence on absence due to illness ${ }^{5}$. This can be due to accidents having primarily influence on shortterm absence due to illness. Due to the high incidence of accidents the related short-term absence is very important

The authors use the term "accident" for the event that caused the injury. Injuries caused by accidents are one of the most frequent causes of contact with hospitals, and are for the population less than 40 years of age the most frequent cause of death in Denmark $^{6} . \ln 2005$, emergency departments (ED) in 
Absence from work due to occupational and non-occupational accidents, page 5

Denmark treated injuries resulting from some 73,000 occupational accidents, 44,000 traffic accidents, and 446,000 accidents in the home or during leisure-time activities ${ }^{7}$. The total number of injuries from accidents in the EU is 40 million $^{8}$. Considerable knowledge has been accumulated regarding the incidence of accidents ${ }^{9-10}$, the seriousness of the injuries and the causal factors ${ }^{11-16}$. Some knowledge exists regarding the societal consequences ${ }^{17-18}$. Absenteeism has been studied separately for e.g. sport accidents $^{19}$, home and leisure accidents ${ }^{20}$, and occupational accidents. For the accidents at work most research has focused on specific occupations such as construction workers ${ }^{21}$, young people ${ }^{22-23}$ etc. However, there is a lack of population-based studies of injury-related absence from work. Absence from work should include not only the victim's absence, but also the related absence from work that relatives or colleagues may have. Therefore injuries in children, young people, elderly people or persons who are unemployed must also be included in the study. Absence categories for the study was created as showed in table 1

\section{$<$ Insert Table 1>}

Knowledge of the accidents' consequences is crucial when giving priority to prevention efforts. Normally, the aim is to focus prevention efforts on the accidents that result in fatalities or the more serious injuries that have additional long-term effects, and not so much on minor accidents. Since the more serious accidents comprise only a small share of all accidents, simply counting injuries (e.g. of those treated at EDs) can be misleading. Similarly, fatalities are relatively few and may give an important but skewed picture of the accident incidence ${ }^{24}$. It is therefore necessary to analyse the consequences of injuries related to the various types of accidents, as well as the consequences for enterprises with regard to absence from work due to accidents. This knowledge can contribute to a more differentiated picture of the burden of accidents for the enterprises and for the society.

Rikhardsson's study of the economic consequences of occupational accidents for enterprises ${ }^{25}$ shows 
Absence from work due to occupational and non-occupational accidents, page 6

that each injured person costs enterprises an average of 4,200 euro of which more than $60 \%$ was due to absence from work. If absence due to non-occupational accidents were added to this, it would give an important picture of the total cost of accidents to production. Registers may provide information on absence, but due to the compensation rules in Denmark short-term absence is under reported depending on industry.

Previous analyses of accidents' consequences for enterprises have only included occupational accidents. In the present study we want to document the absence from work regardless of the type of accident and where it occurs. The Danish Injury Register collects information from four ED's in Denmark, and is evaluated to be representative for the Danish population. This register has extensive information on accidents in Denmark, based on the NOMESCO classification 4th Edition ${ }^{26}$ and therefore provides useful information for the present study.

\section{Method}

This investigation is based on injured persons treated at two ED's, located in the municipalities of Esbjerg and Randers, Denmark. The total catchment area includes roughly 350,000 inhabitants corresponding to $6.5 \%$ of the Danish population and is to a large extent representative for the Danish population with regards to employment and injury types (Table 2).

\section{$<$ Insert Table 2>}

These two ED's already produced detailed records of the external causes of injury for the Danish Injury Register. During the period from August 2008 to May 2009 (total 10 month), all victims of accidents contacting the ED's on randomly selected days were invited to participate in the study. With regard to injuries that led to hospital admissions, also persons with hospital contact the following day were invited to participate, in order to achieve greater representation of severe injuries. Only non-fatal 
injuries were included. A total of 2,284 persons were invited participate in the study. The interviews were carried out by five trained interviewers.

The invited persons were contacted by telephone 11/2-3 months after the accident using a computerassisted telephone interview allowing a customised flow of closed questions, dependent on e.g. their job situation. For injured children, one of the parents was interviewed. At the interviews, it was ensured that the reporting was related to the registered injury.

\section{VARIABLES}

From the Danish injury register information on age, gender, the type of injury (e.g. fracture), cause of the injury (e.g. fall), and setting (traffic, work, sport, or other home/leisure) was obtained. From the interview information was obtained on occupation, partner's occupation, own absence and absence for partner's, colleagues etc. Absence was reported in days and hours, and for persons who were still absent from work at the time of the interview they were asked to estimate their future absence from work. The interview information was linked to the injury register information.

\section{ANALYSIS}

When calculating the average absence from work, individual data were weighted based on to the sampling probability and response rate by age $(0-17 ; 18-64 ; 65-79 ; 80+)$ and gender. The analysis was based on the following categories: occupational accidents; non-occupational accidents among employed persons; and accidents among other persons (table 1).

The persons who were not employed were grouped into children (0-17 years), adults (18-64 years), and the elderly (65+ years). In the analysis, mean absence from work was calculated for the different types of accidents, according to type of injury, and cause of the accident. The type of injury was based on considerations of seriousness of the injury as well as the limitations given by the sample size. 
Absence from work due to occupational and non-occupational accidents, page 8

Due to the skewness of the distribution of absence days, differences between person groups, injury types etc. were tested using Kruskal-Wallis test (PROC NPAR1WAY, SAS version 9.2). The level of significance was 5\%. The mean absence was calculated using PROC SURVEYMEANS (SAS version 9.2). The national figures on absence from work were estimated based on incidence rate of injuries treated at Danish hospitals ${ }^{27}$ and population and employment data from Statistics Denmark ${ }^{28}$.

\section{Results}

Of the 2,284 persons invited to participate, a total of 1,479 interviews were carried out (response rate $64.8 \%)$. The response rate was largest for parents of children (73\%) and lowest for those over 80 years of age (31\%). There were no significant differences in response rate within the age groups. Nonresponse was primarily due to lack of contact information (9\%), not being able to make telephone contact (12\%), refuse to answer (5\%), or other reasons, e.g. dementia or deafness (9\%).. Interviews took place an average of 56 days after contact with the ED ( $S D=15$ days). Among the 1,479 persons injured, the primary injuries were 371 (25\%) contusions, 330 (22\%) open wounds or bruises, 280 (19\%) sprain or strain injuries, 272 (18\%) fractures or amputations, 54 (4\%) concussions, 44 (3\%) injuries to muscles or nerves, $24(2 \%)$ burns, and $104(7 \%)$ other or unspecified injuries. Of the 1,479 persons interviewed, $22 \%$ reported their own absence from work, $18 \%$ reported that others have been absent from work, and $36 \%$ reported that either they themselves or others had absence from work. At the time of the interview, 28 interviewee were still absent from work. Table 3 shows the distribution of the 1,479 interviewed persons according to type of accidents and absence categories.

\section{< Insert Table 3>}

The 202 occupational accidents caused an average absence from work of 5.50 workdays. The absence of the injured accounted for 5.36 workdays and 0.14 workdays represents absence by other persons (see table 2). 0.31 workdays of absence were based on the expectancy among those who were still 
Absence from work due to occupational and non-occupational accidents, page 9

absent at the time of the interview. The average absence for injured persons with job was 10.14 workdays for road traffic accidents, 6.66 workdays for sports accidents, and 8.24 workdays for home and leisure-time accidents. Road traffic accidents and home and leisure-time accidents caused more absence per injury than did occupational accidents ( $p=0.03$ for the difference between groups). At the same time, the number of non-occupational accidents for persons with jobs was greater than the number of occupational accidents. This means that only $27 \%$ of the absence related to injuries among persons with jobs was related to occupational accidents. Table 4 shows the distribution of absence by type of accident and absence category.

\section{< Insert Table 4>}

In the interview group, there were a total of 913 accidents for persons without job. The absence from work that is found in connection with these persons' injuries and thus only involves other persons' absence from work was in mean 0.67 days, most for injuries in children (0.91 days) and least for injuries in the elderly (0.12 days). For all adults, regardless of their employment status, there were 549 non-occupational injuries for those interviewed; 364 (66\%) of these injuries involved persons with jobs and 185 (34\%) involved persons without jobs. Table 5 shows that length of absence depends on the type of injury $(p<0.0001)$. Bone fractures and amputations (amputations are only represented by six cases) cause average absence for employed persons of 21-22 workdays, regardless of whether the injury was occupational or non-occupational.

\section{$<$ Insert Table 5>}

For other injuries not requiring hospitalisation, absence for employed persons was shorter for occupational accidents than for non-occupational accidents $(p=0.04)$.

The length of absence among employed persons differed between the causes of the accident $(p<0.0001) ;$ "inappropriate movements" and "falls" caused the longest absences (Table 5). 
Absence from work due to occupational and non-occupational accidents, page 10

Inappropriate movements are ex incidents when the injured person has en overexertion of the body when pulling, pushing, carrying, turning etc. Among all injured, falls caused less average absence, since many injuries due to falls occurred in elderly without jobs. "Malfunction and loss of control of machinery, equipment and materials" caused more days of absence when they occur outside work than at work ( $p=0.03$ ). "Malfunction and loss of control of means of transport" and "falls" caused the same amount of absence regardless of whether accidents occurred at work or outside work $(p=0.29$ and $p=0.89$, respectively). In total 567,543 were injured in Denmark in 2007 corresponding to an incidence rate of 104 annually per 1000 persons (ED data, National Patient Registry), and assuming a mean absence of 3.21 days per accident, the total absence in Denmark is $1,822,000$ workdays. As there in Denmark were 2.84 million employed the absence per employed person due to accidents becomes 0.641 workdays annually. Of these, 0.160 days are related to occupational injuries, 0.404 days are related to non-occupational injuries in employed persons, 0.066 days are related to injuries in children, 0.008 are related to injuries in adults without job, and 0.003 days are related to injuries in the elderly.

\section{Discussion}

Injuries caused by occupational accidents treated at hospitals led to an average absence from work of 5.50 days, while non-occupational accidents among employed caused an average absence from work of 8.06 days. Since non-occupational accidents are far more frequent than occupational accidents, the major part of the injury-related absence from work is related to non-occupational accidents. In relation to an average absence of about 11 days annually per fulltime employee ${ }^{17}$, absence from work due to all accidents amounts to about $6 \%$ of the total absence due to illness in Denmark. The mean absence found in the present study is shorter than the 32 days found for home and leisure accidents among employed in a French electricity and gas company ${ }^{20}$. Part of the reason for the longer absence 
Absence from work due to occupational and non-occupational accidents, page 11

may be that only accidents causing sick leave were included here, but even when taking this into account, the present study shows less absence than the French study. For sports accidents, a mean absence of 7-8 days were found in Flanders ${ }^{19}$, which is close to what was found among employed in the present study. In a Danish study ${ }^{21}$ the mean absence for occupational accidents among construction workers was 12 days, somewhat more than in the present study, but included only accidents reported to the National Working Environment Authority in Denmark. Since only accidents causing at least one day of absence from work are reported, the mean absence would be expected to be longer. In general, mean absence should always be assessed in relation to criteria for the accidents to be included and accordingly the incidence rate. E.g. in the French study ${ }^{20}$, the incidence rate of home and leisure accidents was between 6 and 26 annually per 1000 dependent on work grade, compared to 104 per 1000 in the present study including all accidents. There are several limitations to the study. Fatal accidents were not included, although accidents are the most common cause of death in adults under 40 years of age, causing a great loss also in relation to work. The interviewees reported sick leaves extending beyond the time of the interview. Their estimation of this may be uncertain and probably result in underestimation of the total sick leave. Further, long-term consequences such as disability retirement were not included in the present study, since these have been studied previously ${ }^{18,29}$. Furthermore, injuries that are not hospital treated are not included in the study. A previous study have shown that only $53 \%$ of injuries in adults are hospital treated ${ }^{30}$, so although the treatment rate for severe injuries may be higher than this, the absence may be underestimated. This underestimation may be different in the different arenas, probably due to differences in injury severity: while $61 \%$ of the traffic injuries are treated at a hospital, only $44 \%$ of the sports injuries are $\mathrm{so}^{30}$ 
Absence from work due to occupational and non-occupational accidents, page 12

The relatively small sample size may explain the large standard errors in some subgroups and why significant differences were not found in some cases. The response rate was low among the oldest persons, and although this was adjusted for, it may be assumed that especially the weakest elderly have not answered. The absence related to this group may therefore be underestimated, but this hardly changes the total absence, since this entails very little absence in relation to the elderly' accidents. Although the employment rate in the hospitals' catchments areas was the same as at national average, the area has a somewhat larger share of industrial workplaces. This may influence the absence pattern towards more workplace injuries. Several factors lead us to assume that the calculated absence figures are actually a minimum. The first reason for this is that $28 \%$ of those interviewed stated that they had no absence due to the accident, in spite of the fact that they were taken to the ED. This can be because they went to the ED after work or could take time off due to overtime, but it could also be that they did not consider it absence if they returned to work after being treated. A second factor is that the accidents that cause back injuries, often as a result of heavy lifting, are not usually sought treated at ED's, or are not registered as related to accidents; it is well known, however, that such injuries often cause long sick periods. Further, injuries may have consequences for work even though they do not necessarily lead to absence. These are cases where the accident victim is able to go to work but cannot fully perform work functions. Finally, the interviews revealed that vacation days, free time to compensate for overtime, free time to care for sick children, and leave are used to manage some of the effects of accidents.

The present study reveals consequences from accidents for employment that have not been in focus before. Even though enterprises are only responsible for the accidents that occur in connection with work, they can have an interest in their employees not becoming involved in accidents outside work. In addition, as pointed out by $\rfloor \emptyset r g e n \operatorname{sen}^{23}$, many of the accidents occurring at work have the same 
Absence from work due to occupational and non-occupational accidents, page 13

characteristics as those that occur outside of work; therefore, a potential exists in broad efforts to prevent these accidents. For example, an effort to reduce falling accidents for the whole population would affect both occupational accidents and home and leisure-time accidents with quite large coordinated gains. Finally, the results point to the need to communicate to the population and to enterprises the consequences of the accidents and the possibility to prevent them. There are in many ways focus on occupational and traffic accidents, but prevention of home and leisure-time accidents is lacking, even though they are more frequent. The problem is that knowledge about these is not present in the public, and the ways in which non-occupational accidents can be avoided are enclosed in silence.

\section{Conclusion}

Absence due to accidents contributes to a considerable part of the total absence from work, and nonoccupational accidents cause more absence than did occupational accidents. Although small, absence from work due to other persons' accidents should not be neglected.

\section{Acknowledgements}

The work was supported by Trygfonden [grant no. 7585-07]. 
Absence from work due to occupational and non-occupational accidents, page 14

\section{Key Points:}

- The first aid hospital treated accident inury causes in mean 3.21 days of absence

- Occupational accidents treated at hospitals led to an average absence from work of 5.50 days

- Non-occupational accidents among employed and other persons led to an average absence from work of 8.06 days

- $6 \%$ of the total absence from work due to illness is caused by accidents

- Falls and i nappropriate movements like overexertion of the body when pulling, puching, carrying, turning etc. caused the longest absence 
Absence from work due to occupational and non-occupational accidents, page 15

\section{References}

1. European Foundation for the Improvement of Living and Working Conditions 2010, "Absence from work", www.eurofound.europa.eu

2. The Danish government plan of action for reducing the absence from work 2008, " Sygefravær - en fælles udfordring (Absence from work - a joint challenge)

3. European Working Conditions Observatory 2007, "Factors influencing sickness absence", www.eurofound.europa.eu/ewco/2007/08/DK0708019I.htm

4. CIPD 2003, "Employee absence 2003 - a survey of management policy and practice", www.cipd.co.uk

5. Labriola M., Lund T., Christensen K.B., 2007, “Resultater af sygefraværsforskning 20032007 (The results from research in absence due to illness 2003-2007)", NFA, Denmark

6. The Danish government's health care programme, 2002. "Sund hele livet" [Lifelong health],

7. National Board of Health [Sundhedsstyrelsen] 2005, "Skadestuernes virksomhed" [The work of the Casualty Wards]

8. Bauer R and Steiner M: Injuries in the European Union. Statistics Summary 2005-2007. Kuratorium für verkehrssicherheit, Vienna, 2009

9. Polinder S, Haagsma JA, Toet $\mathrm{H}$, Brugmans MJ, van Beeck EF, EUROCOST and APOLLO reference groups, 2010 "Burden of injury in childhood and adolescence in 8 European countries" BMC Public health 10:45

10. Greenspan Al, Coronado VG, Mackenzie EJ, Schulman J, Pierce B, Provenzano G, 2006, "Injury hospitalizations: using the nationwide inpatient sample." J Trauma 61(5): 1234-43

11. Sleet DA, Ballesteros MF, Borse NN, 2010, "A review of unintentional injuries in adolescents". Annu Rev Public health 31:195-212

12. Härlein J, Dassen T, Halfens RJ, Heinze C, 2009, "Fall risk factors in older people with dementia or cognitive impairment: a systematic review “. J Adv Nurs 65(5): 922-33

13. Drebit S, Shajari S, Alamgir H, Yu S, Keen D, 2010, “Occupational and environmental risk factors for falls among workers in the healthcare sector. " Ergonomics 53(4):525-36

14. Robb G, Sultana S, Ameratunga S, Jackson R, 2008, "A systematic review of epidemiological studies investigating risk factors for work-related road traffic crashes and injuries. "Inj Prev 14(1):51-8

15. LaFlamme L, Eilert-Petersson E, 2001, “Injury risk and socio-economic groups in different settings", Eur J Public Health 2001:11,309-13.

16. Jørgensen $K, 2008$, "A systematic use of information from accidents as a basis of prevention activities", Safety Science, vol.46,Issue 2, pg 164-175, Elsevier

17. Lauritsen J, Kidholm K, Skov O, Nørgård L, 2002, [Average costs and proportion of total costs related to hospital registered injuries.] In Danish., Ugeskr Læger 164(44),5107-12 
Absence from work due to occupational and non-occupational accidents, page 16

18. Tüchsen F, Christensen KB, Feveile H, Dyreborg J, 2009, "Work injuries and disability", J Safety Res 40(1):21-4

19. Cumps E, Verhagen E, Annemans L, Meeusen R, 2008, "Injury rate and socioeconomic costs resulting from sports injuries in Flanders: data derived from sports insurance statistics 2003". Br J Sports Med 42(9):767-72

20. Verrier A, Chevalier A, Home and leisure injury group, 2007, "Home and leisure injuries among the French electricity and gas company active employees: circumstances and short-term consequences." Accid Anal Prev 39(6):1279-85

21. Kines P, Spangenberg S, Dyreborg J, 2007, "Prioritizing occupational injury prevention in the construction industry: Injury severity or absence?" J Safety Res 38(1):53-8

22. Koehoorn M., Breslin F.C., Xu F., 2008, "Investigating the Long-Term Health Consequences of Work-Related Injuries Among Youth.", J Adolescent Health 43: 466-473

23. Jørgensen K, 2007, "Unges ulykker på arbejde og i hjem- og fritiden" [Young people's accidents at work and at home and during leisure time], Report to HTS, Copenhagen

24. Laursen B, Nielsen LT, Christensen PH, Møller H, Frimodt-Møller B, 2006, "Børneulykker i Danmark. En registerbaseret analyse" [Children's accidents. A register-based analysis]. National Institute for Public Health, Copenhagen

25. Rikhardsson P, Impgaard M, 2004, "Corporate Cost of Occupational Accidents: An Activity Based Analysis", Journal of Accident Analysis and Prevention, Vol. 36, Issue 2, pp 173-182.

26. NOMESCO 2007, "Nomesco Classification of External Causes of Injuries - fourth revised edition", NORDEN, Nordic Council of Ministers

27. National Patient Registry, National Board of Health - special analysis.

28. Statistics Bank, Statistics Denmark. www.statistikbanken.dk, accessed June 15, 2010.

29. Hannerz H, Mikkelsen KL, Nielsen ML, Tüchsen F, Spangenberg S, 2007, "Social inequalities in injury occurrence and in disability retirement attributable to injuries: a 5-year follow-up study of a 2.1 million gainfully employed people." BMC Public Health 7:215

30. Laursen B, Frimodt-Møller B, 2002, "Sociale forskelle i brug af sundhedsvæsenet i forbindelse med ulykker" [Socioeconomic differences in accident-related health care],Ugeskrift for Læger, nr 164 pg 1855-1858 
Table 1 Description of the absence categories and the contents of each category

\begin{tabular}{|l|l|l|}
\hline Absence categories & $\begin{array}{l}\text { Accidents at work } \\
\text { incl. traffic at work }\end{array}$ & $\begin{array}{l}\text { Accidents not at work } \\
\text { Traffic, sport, leisure-time }\end{array}$ \\
\hline $\begin{array}{l}\text { Absence, injured in work } \\
\text { For victims who has a job }\end{array}$ & $\begin{array}{l}\text { Includes victims absence from } \\
\text { his job and the absence for } \\
\text { others ex colleagues or relatives } \\
\text { from their jobs for helping and } \\
\text { taking care of the victim }\end{array}$ & $\begin{array}{l}\text { Includes victims absence from } \\
\text { his job and the absence for } \\
\text { others ex colleagues or relatives } \\
\text { from their jobs for helping and } \\
\text { taking care of the victim }\end{array}$ \\
\hline $\begin{array}{l}\text { Absence, injures not in work } \\
\text { For victims who has no job, but } \\
\text { Children, Adult, Elderly }\end{array}$ & $\begin{array}{l}\text { Includes only the absence for } \\
\text { others ex colleagues or relatives } \\
\text { from their jobs for helping and } \\
\text { taking care of the victim }\end{array}$ & $\begin{array}{l}\text { Includes only the absence for } \\
\text { others ex colleagues or relatives } \\
\text { from their jobs for helping and } \\
\text { taking care of the victim }\end{array}$ \\
\hline
\end{tabular}


Absence from work due to occupational and non-occupational injuries, table 2

Table 2. Representativeness of hospital catchment areas, 2008

\begin{tabular}{lllll}
\hline & Esbjerg hospital & $\begin{array}{l}\text { Randers } \\
\text { hospital }\end{array}$ & Denmark, total & $\begin{array}{l}\text { Esbjerg+Randers, } \\
\text { Per cent of } \\
\text { Denmark, total }\end{array}$ \\
\hline $\begin{array}{l}\text { Catchment } \\
\text { population }\end{array}$ & 207,000 & 151,000 & $5,486,000$ & $6.5 \%$ \\
$\begin{array}{l}\text { Employed } \\
\text { population }\end{array}$ & 110,000 & 70,000 & $2,850,000$ & $6.3 \%$ \\
$\begin{array}{l}\text { Injury ED contacts } \\
\text { Injury admissions }\end{array}$ & 27,488 & & & \\
$\begin{array}{l}\text { Fracture, crush, } \\
\text { amputation }\end{array}$ & 4,383 & 19,689 & 663,319 & $7.1 \%$ \\
$\begin{array}{l}\text { Lesion of muscles } \\
\text { and nerves }\end{array}$ & 344 & 2,547 & 82,619 & $7.6 \%$ \\
$\begin{array}{l}\text { Work accident } \\
\text { Traffic accident }\end{array}$ & 3,971 & 3,220 & 109,247 & $7.0 \%$ \\
\hline
\end{tabular}

Data are based on Statistics Denmark and the National Patient Registry

*Work and traffic injuries require coding of external cause of the injury. For Esbjerg and Randers hospitals, $92 \%$ of the injury cases were coded compared to $79 \%$ in Denmark as a whole. This may result in a seemingly higher share of these injuries. 
Table 3. Number interviewed by absence category and accident type

\begin{tabular}{|c|c|c|c|c|c|}
\hline \multirow{2}{*}{ Absence category } & \multicolumn{5}{|c|}{ Accident type } \\
\hline & $\begin{array}{l}\text { Occupational } \\
\text { accident }\end{array}$ & Traffic accident & Sports accident & $\begin{array}{l}\text { Home and } \\
\text { leisure-time } \\
\text { accident, other }\end{array}$ & Total \\
\hline $\begin{array}{l}\text { Absence, injured } \\
\text { in work }\end{array}$ & & & & & \\
\hline $\begin{array}{l}\text { Injured with job } \\
\text { Absence, injured } \\
\text { not in work }\end{array}$ & 202 & 54 & 101 & 209 & 566 \\
\hline Injured is a child & 0 & 45 & 158 & 387 & 590 \\
\hline $\begin{array}{l}\text { Injured is an adult } \\
\text { not at work }\end{array}$ & 0 & 21 & 34 & 130 & 185 \\
\hline $\begin{array}{l}\text { Injured is an } \\
\text { elderly not at work }\end{array}$ & 0 & 12 & 0 & 126 & 138 \\
\hline Total absence & 202 & 132 & 293 & 852 & 1479 \\
\hline
\end{tabular}


Table 4. Absence from work per accident in average, by accident type and absence category. Days, mean (95\% confidence interval)

Accident type

\begin{tabular}{|c|c|c|c|c|c|}
\hline Absence category & $\begin{array}{l}\text { Occupational } \\
\text { accidents }\end{array}$ & $\begin{array}{l}\text { Road traffic } \\
\text { accidents }\end{array}$ & Sports accidents & $\begin{array}{l}\text { Other home and } \\
\text { leisure-time } \\
\text { accidents }\end{array}$ & All accidents \\
\hline \multicolumn{6}{|l|}{$\begin{array}{l}\text { Absence, injured at } \\
\text { work }\end{array}$} \\
\hline $\begin{array}{l}\text { The Injured } \\
\text { absence }\end{array}$ & $5.36(3.52-7.20)$ & $9.76(5.40-14.11)$ & 6.37 (3.85-8.89) & $8.15(5.98-10.31)$ & $6.95(5.76-8.15)$ \\
\hline Others absence & $0.14(0.05-0.22)$ & $0.38(0.00-0.79)$ & $0.29(0.03-0.55)$ & $0.09(0.02-0.16)$ & $0.17(0.10-0.24)$ \\
\hline \multicolumn{6}{|l|}{$\begin{array}{l}\text { Absence, injures not } \\
\text { at work }\end{array}$} \\
\hline $\begin{array}{l}\text { Others absence } \\
\text { when the Injured is a } \\
\text { child }\end{array}$ & None & $1.12(0.26-1.97)$ & $0.69(0.45-0.93)$ & $0.98(0.73-1.23)$ & $0.91(0.73-1.09)$ \\
\hline $\begin{array}{l}\text { Others absence } \\
\text { when the Injured is } \\
\text { an adult not at work }\end{array}$ & None & $0.70(0.00-1.43)$ & $0.15(0.00-0.36)$ & $0.30(0.00-0.88)$ & $0.32(0.00-0.73)$ \\
\hline $\begin{array}{l}\text { Others absence } \\
\text { when the Injured is } \\
\text { an elderly not at } \\
\text { work }\end{array}$ & None & $0.00(0.00-0.00)$ & None & $0.13(0.02-0.24)$ & $0.12(0.01-0.22)$ \\
\hline Total absence & $5.50(3.65-7.34)$ & $4.66(2.69-6.63)$ & $2.79(1.79-3.78)$ & $2.56(1.96-3.17)$ & $3.21(2.70-3.72)$ \\
\hline
\end{tabular}


Table 5. Total absence from work related to the type of injury, cause of accident, and absence categories. Days, mean, $95 \%$ confidence interval, and number of interviewed

\begin{tabular}{|c|c|c|c|c|}
\hline \multirow[b]{2}{*}{ Type of injury } & \multicolumn{4}{|c|}{ Absence categories } \\
\hline & $\begin{array}{l}\text { Absence, } \\
\text { occupational } \\
\text { accidents } \\
\end{array}$ & $\begin{array}{l}\text { Absence, other } \\
\text { accidents, injured } \\
\text { persons in job }\end{array}$ & $\begin{array}{l}\text { Absence. other } \\
\text { accidents, injured } \\
\text { person not in job }\end{array}$ & $\begin{array}{l}\text { Absence, all } \\
\text { accidents }\end{array}$ \\
\hline $\begin{array}{l}\text { Fracture, crushing, } \\
\text { amputation }\end{array}$ & $21.1(6.6-35.6) \mathrm{N}=12$ & $20.8(13.7-27.9) \mathrm{N}=54$ & $1.2(0.6-1.7) \mathrm{N}=206$ & $6.1(4.2-7.9) \mathrm{N}=272$ \\
\hline $\begin{array}{l}\text { Lesion of muscles } \\
\text { or nerves }\end{array}$ & $46.3(0.0-99.0) \mathrm{N}=6$ & $21.7(9.4-33.9) \mathrm{N}=21$ & $0.4(0.0-0.8) \mathrm{N}=17$ & $16.9(7.8-26.0) \mathrm{N}=44$ \\
\hline $\begin{array}{l}\text { Admitted, other } \\
\text { injuries }\end{array}$ & $27.8(0.0-64.2) \mathrm{N}=6$ & $15.9(7.0-24.7) \mathrm{N}=22$ & $1.6(0.2-3.0) \mathrm{N}=64$ & $6.8(3.5-10.1) \mathrm{N}=92$ \\
\hline $\begin{array}{l}\text { Not admitted, } \\
\text { other injuries }\end{array}$ & $3.1(2.1-4.1) \mathrm{N}=178$ & $4.6(3.3-5.8) \mathrm{N}=267$ & $0.4(0.3-0.5) \mathrm{N}=626$ & $1.9(1.6-2.3) \mathrm{N}=1071$ \\
\hline \multicolumn{5}{|l|}{$\begin{array}{l}\text { Cause of the } \\
\text { accident }\end{array}$} \\
\hline $\begin{array}{l}\text { Malfunction or loss } \\
\text { of control of } \\
\text { machinery, } \\
\text { equipment and } \\
\text { materials }\end{array}$ & $3.1(1.6-4.6) \mathrm{N}=112$ & $6.0(3.1-8.9) \mathrm{N}=63$ & $0.2(0.0-0.3) \mathrm{N}=111$ & $2.6(1.7-3.5) \mathrm{N}=286$ \\
\hline $\begin{array}{l}\text { Malfunction or loss } \\
\text { of control of means } \\
\text { of transport }\end{array}$ & $7.7(0.0-16.7) \mathrm{N}=5$ & $9.7(5.5-13.8) \mathrm{N}=58$ & $0.7(0.3-1.1) \mathrm{N}=84$ & $4.5(2.8-6.3) \mathrm{N}=147$ \\
\hline $\begin{array}{l}\text { Falls to lower or } \\
\text { same level }\end{array}$ & $8.2(1.8-14.6) \mathrm{N}=17$ & $10.6(6.3-15.0) \mathrm{N}=81$ & $0.6(0.4-0.8) N=365$ & $2.7(1.8-3.6) \mathrm{N}=463$ \\
\hline $\begin{array}{l}\text { Inappropriate } \\
\text { movements }\end{array}$ & $15.6(4.3-26.8) \mathrm{N}=25$ & $10.0(5.9-14.1) \mathrm{N}=73$ & $0.8(0.2-1.4) \mathrm{N}=131$ & $5.4(3.5-7.3) \mathrm{N}=229$ \\
\hline $\begin{array}{l}\text { All other causes of } \\
\text { accidents }\end{array}$ & $4.7(1.5-8.0) \mathrm{N}=43$ & $4.6(2.6-6.7) \mathrm{N}=89$ & $0.8(0.5-1.1) \mathrm{N}=222$ & $2.3(1.6-3.0) \mathrm{N}=354$ \\
\hline All injuries & $5.50(0.94) \mathrm{N}=202$ & $8.1(6.5-9.6) \mathrm{N}=364$ & $0.6(0.5-0.8) \mathrm{N}=913$ & $3.2(2.7-3.7) \mathrm{N}=1479$ \\
\hline
\end{tabular}

